\title{
Article \\ Implementation of Virtual Training: The Example of a Faculty of Computer Science during COVID-19 for Sustainable Development in Engineering Education
}

\author{
Khairan Rajab (D), Mohammed Hamdi *(D), Mana Saleh Al Reshan (D), Yousef Asiri (D), Asadullah Shaikh (iD \\ and Adel Rajab
}

Citation: Rajab, K.; Hamdi, M.; Al Reshan, M.S.; Asiri, Y.; Shaikh, A.;

Rajab, A. Implementation of Virtual

Training: The Example of a Faculty of Computer Science during COVID-19 for Sustainable Development in Engineering Education. Electronics 2022, 11, 694. https://doi.org/ 10.3390/electronics11050694

Academic Editors: Nikolay Hinov, Radi Romansky and George A. Tsihrintzis

Received: 31 December 2021 Accepted: 21 February 2022 Published: 24 February 2022

Publisher's Note: MDPI stays neutral with regard to jurisdictional claims in published maps and institutional affiliations.

Copyright: (C) 2022 by the authors. Licensee MDPI, Basel, Switzerland. This article is an open access article distributed under the terms and conditions of the Creative Commons Attribution (CC BY) license (https:// creativecommons.org/licenses/by/ $4.0 /)$.
College of Computer Science and Information System, Najran University, Najran 55461, Saudi Arabia; kdrajab@nu.edu.sa (K.R.); msalreshan@nu.edu.sa (M.S.A.R.); yasiri@nu.edu.sa (Y.A.); asshaikh@nu.edu.sa (A.S.); adrajab@nu.edu.sa (A.R.)

* Correspondence: mahamdi@nu.edu.sa

\begin{abstract}
Research on faculty engagement in computer science and e-learning environments is limited. Students in computer science majors and courses often cite the lack of engagement of their faculty as a reason for their decision to switch majors, drop out or perform poorly. With the shift to e-learning associated with the current global pandemic, reports of faculty engagement across countries and higher education systems converged to indicate a reduced level of interactivity. Using a cross-sectional sample of 39 lecturers and professors from a southern public university in Saudi Arabia, this manuscript documents empirically the low levels of computer science faculty engagement during the 2020 spring semester (March-May). The study found support for the hypotheses linking higher levels of empathetic instruction, an exhibition of exemplary performance traits, utilization of community building strategies and use of storytelling and students' engagement. The study also found that many faculties need immediate and significant training on making their online instruction more interactive and exciting. Theoretically, the evidence presented confirms the importance of faculty engagement as the main predictor of desirable students' outcomes across e-learning, as well as computer science learning environments.
\end{abstract}

Keywords: faculty engagement; students' engagement; higher education; Saudi Arabia; computer science

\section{Introduction}

The National Academies of Sciences, Engineering and Medicine found that introductory computer science courses lack creativity and interactivity leaving many students disinterested in the discipline [1]. A lack of faculty engagement in the development of students' hard and soft skills is cited among the chief culprits of low retention rates in computer science departments [2-8]. Among all college majors, computer science consistently ranks highest in dropout rates across countries, partly because of diminished faculty's efforts to excite students' instincts to persist through difficult time-consuming courses [9-14]. The Center for Evaluating the Research Pipeline at the Computing Research Association concluded that students' apathy, disinterest and abstention from computer science courses is explained by the absence of interactivity, energy and passion exhibited by faculty in the classroom [15-19]. Recent reports of online learning noted the high withdrawal rates of students from computer science courses across many countries indicating a lack of instructor support systems for completing classes [20-27].

Research on computer science faculty's engagement in e-learning environments is meager [28-33]. Inadequate systematic investigation exists on the extent to which computer science faculty exercise empathetic, performance-based, storytelling-infused, and community creation-oriented instruction [30-34]. Within the Saudi higher education context, little attention has been paid to the level of faculty engagement before, and during the shift to 
e-learning because of COVID-19 [35-38]. Theoretical links between recommended faculty engagement practices and students' outcomes have not been assessed in the Saudi context nor the computer science e-learning environment [39-42]. Measures of faculty engagement applicable to the instructional staff working in Saudi Arabia are unavailable [43-46]. This research addresses such gaps in the literature by presenting the findings of a new original empirical investigation of Saudi's computer science faculty engagement in an e-learning environment in an attempt to improve instruction and enhance students' retention.

This article presents the results of a cross-sectional study on faculty engagement and students' outcomes in a large public Saudi university's computer science department in 2020. A sample of lectures taught by 39 instructors during the Spring of 2020 was analyzed using a newly validated instrument measuring faculty's engagement along four dimensions: (a) use of empathetic instruction/content, (b) exhibition of high-performance traits (public speaking, motivational lecturing and transformational leadership skills), (c) community building strategies' use, and (d) storytelling utilization. Students' engagement measured on three dimensions: cognitive, affective and behavioral was also measured. Logistic regression analysis was used to model the association between faculty engagement, and student engagement in e-learning computer science environments.

The findings suggested that faculty who were ranked as engaged exhibited better student engagement outcomes in their courses. Faculty who utilized empathetic instruction exhibited performance exemplary traits while teaching, employed community building strategies and relied on storytelling yielded higher cognitive, affective, and behavioral student engagement scores. Nevertheless, the results suggested an overall low faculty engagement among Saudi computer science instructors during online teaching. Notably, faculty who were educated in the West, and held a doctoral degree were more likely to be engaged. Evidence confirms the positive significant associations reported elsewhere in the education literature connecting better students' outcomes with empathetic teaching, storytelling, use of exemplary performance traits, and deployment of community-building methods.

This paper contributes to the science of electronics in several respects. First, the investigation recommends best evidence practices on how to teach electronics courses at the higher education level to guarantee better academic performance. Second, the paper offers a fresh perspective on electronics faculty's engagement levels. Most importantly, the findings highlight the needed core competencies in professional development for electronics scientists to be successful in communicating their knowledge to students, as well as members of the public.

The rest of the paper is organized as follows: Section 2 provides the related work. Section 3 presents the basic method techniques. Section 4 is devoted to the demonstration of results, while Section 5 is based on the discussion, along with the future directions. Finally, Section 5 concludes the work.

\section{Related Work}

\subsection{The Role of Engagement in Students' Learning}

Engagement refers to ensuring that students participate actively and invest profoundly in learning in any given educational program or course [47,48]. This conception departs from popular misperceptions of engagement like those characterizing it with comical or flippant learning environments [49-51]. Engagement is grounded in longstanding behavioral literature arguing that optimal learning requires students' motivation, heeding and enjoyment [52-55]. Learning is closely tied to students' emotional states. Education researchers established that prior to actual learning, students must be interested in the material, as well as lively prepared to receive new knowledge to achieve expected outcomes [56].

Students' engagement in higher education is closely linked with students' performance, achievement and learning outcomes. Carini et al. [57] performed a study on 1958 students attending 14 different four-year colleges and universities finding positive associations between different measures of engagement and various metrics of students' performance like grades. Most importantly, the authors suggested that first-year students, those with the low- 
est ability and less prepared for college benefit most from engagement [57]. Kuh et al. [58] found that engagement accounts for an additional 13\% in explaining variation in first-year students' GPA in 18 colleges and universities when included with demographic and prior academic history measures [58]. A number of researchers found students' engagement to be a good predictor of e-learning course completion, satisfaction, and performance $[59,60]$.

Faculty engagement improves students' likelihood of persistence in computer science thereby improving retention rates [61-64]. The faculty's use of emotional hooks and content livening the rigid material in introductory courses make students more likely to funnel their limited cognitive resources to class [65]. The faculty's use of creative storytelling makes students more likely to concentrate on the material presented while lecturing [66-68]. The faculty's deployment of community-building strategies activates the sense of belonging among students making them more likely to devote more time and effort into completing their courses and programs $[69,70]$. The faculty's outstanding performance in public speaking and non-verbal communication skills make students more likely to follow instructions, fulfill course expectations, and learning outcomes [71,72].

\subsection{The Crisis of Engagement in Higher Education}

The Inside Higher Ed Survey of College and University Faculty Workplace Engagement concluded that $34 \%$ of surveyed faculty reported adequate levels of engagement in their work. Another survey by Gallup suggested that $52 \%$ of academics indicated a lack of engagement in their jobs [73]. A study at the University of Virginia showed that $80 \%$ of 300 surveyed STEM faculty are not engaging and do not practice active learning strategies [74].

\subsection{Faculty Engagement and the Global Pandemic}

The COVID-19 global pandemic has exacerbated the retention problem for computer science departments [75]. Faculty pre-record their lectures, post their PowerPoint presentations and notes without further engagement in many asynchronous environments or courses [76,77]. Faculty do not exhibit adequate emotional and empathetic interest in the professional and personal development of their students leading to diminished interest in courses and the field [78]. Faculty assign less collaborative/group projects that lower levels of belonging and commitment to the course among students, a feature that has been demonstrated to enhance retention, completion and success [79,80]. Faculty do not deliver lectures to a live audience of students missing out on the power of storytelling, charismatic motivation and transformational leadership effects that activate the limited cognitive learning assets endowed by students and motivate them to exert more effort and succeed in the course [81]. Faculty deliver e-learning lectures as machine readers without exemplary performance and adequate attention to immediacy cues, non-verbal communication signals, causing a less attentive audience [82,83].

\subsection{The Practice of Engagement in the Classroom}

The use of emotional appeals in classrooms stimulates students' engagement [84-87]. Students have limited cognitive resources to dedicate to learning in the classroom [88,89]. Past behavioral research has concluded that students' amount of attention and working memory for learning are scarce and need to be efficiently invoked by strategies like emotional hooks [90-92]. Breaking down lectures into manageable segments where emotional content is introduced serves as an effective way of increasing students' engagement [93-95]. The use of provocative videos, images, stories, or scandals stimulates the attention and cognitive powers of students [96]. Another technique that stimulates scarce students' cognitive assets is the use of relevant cultural and social content [97]. Faculty utilize discussions of contemporary social movements, events or cultural symbols that relate to students' immediate lives [98]. Further, engaging faculty invite students to resolve a specific problem or puzzle facing the institution, discipline or community. In addition, students are more alert when the content is presented in a joyful manner and the faculty is incorporating humor 
into the class discussions [99]. One of the proven ways of increasing students' engagement is routine interruption $[100,101]$. Students who are surprised by a positive change in the learning environment are more likely to dedicate further investment to their class [102].

Instructors' performance before their students influences their engagement [96]. The injection of enthusiasm and excitement by instructors has a contagious effect on students who become more interested in the material once they feel the passion for the subject exhibited by their teachers [4,7]. Faculties who excel in the deployment of immediate cues, non-verbal communication skills, generate more engagement [72]. Faculty who excel in public speaking and performing before large audiences generate higher levels of interest and energy in their classrooms [76].

The inculcation of a community sense in the classroom increases students' participation and engagement throughout the duration of the course [99]. that all students perceive themselves as included, valued, and part of a larger social group yields better involvement [56]. Instructors who construct a sense of belonging generate more interested bodies of students [97]. Faculty who design their courses on principles of collaborative learning, participatory decision-making over instruction/assessment strategies and democratic educational practices yield more engaged classrooms [103]. Faculty who remember their students' names, ensure that every student is heard, personalize instruction and act as a group leader with a shared vision of achieving exemplary learning outcomes endanger better participation rates from students [98,104].

Stylized storytelling activates students' attention and maximizes learning engagement in the classroom. Faculty who share their own personal stories, narratives on their peers, historical figures, political candidates, or charismatic leaders generate more engaged learners in their classrooms $[67,70]$. Faculty who encourage students to share their own stories also increase the level of cognitive attention invested by class peers [68,71]. Presenting the fields' development, puzzles or future trends in detailed narratives describing key figures, scenes and outcomes increase students' interest in consuming the material presented [80].

\subsection{Faculty Engagement in Saudi Higher Education}

Saudi faculty have low levels of students' engagement in their classrooms. They are inundated with heavy course loads [105]. They do not receive training or professional development workshops on students' engagement and its importance [106]. Many are unaware of the importance of engagement for achieving optimal learning outcomes [107]. More importantly, many do not receive formal coursework in pedagogy and effective instruction prior to assuming their academic positions [108]. They are expected to deliver mandated curriculum by the Ministry of Education, their colleges and departments without room for altering the curriculum [109]. They lack incentives to change their traditional lecturing methods in the classroom. This has led to the presence of qualified faculty who do not inject energy, enthusiasm and excitement in the classroom generating students' disinterest, apathy and jadedness $[43,110]$.

Research on faculty endeavors in encouraging engagement in Saudi classrooms highlights the potential of a set of pedagogical, as well as instructional strategies. Eissa [103] pointed to the positive impact of digital storytelling in improving student's performance in English as a Foreign Language classes at Northern Borders University. Alkhalaf et al. [111] concluded that students reported higher satisfaction, enjoyment and participation levels in courses that mandated collaborative and group projects. Khurshid [104] found that charismatic, participatory, and democratic teaching styles yield more engaged students in a study at Jazan University. Abdel-Jaber [112] analyzed the covariates of students' satisfaction at the Arab Open University in Eastern Saudi Arabia and found that instructor's interactivity is the single most predictor of students' enjoyment and participation in virtual courses. Alsamani and Daif-Allah [113] suggested that group-based projects generate better students' interest and performance in computer science courses taught in English at Al-Qassim University in central Saudi Arabia. 


\section{Methods}

This research is a quantitative cross-sectional design study investigating the association between faculty engagement and students' engagement in Saudi Arabia. The sample is all teaching faculty from the Computer Science/Information Systems departments at Najran University. The time of the study was during the shift to e-learning in March-May 2020 due to the COVID-19 global pandemic. Instruments were developed and validated to be used for rating by trained faculty at the same institution. The scientific research committee approved the study once all procedures were cleared and a grant was received to support the researchers' endeavors in completing this research.

\subsection{Data Sources}

A new dataset to measure faculty's engagement and student engagement in virtual classes at the Computer Science/Information Systems departments was constructed to assure the quality of teaching during COVID-19. The data is composed of independent ratings of 23 items by four trained observers who are full-time faculty at different departments at the university. The data is cross-sectional where rows represent the instructor's engagement, as well as his students' engagement outcomes and columns are attributes of faculty and student engagements. A total of 24 columns, 20 items measuring faculty engagement and four items measuring students' engagement, and 39 rows each representing an instructor at both the males and females campuses. Note that more columns were constructed by composing new variables using existing attributes to be used in the analysis.

\subsection{Participants}

Thirty-nine instructors participated in this research. They had varying levels of tenure, work experience and research areas. All participants were full-time instructors at their respective departments. All of them hold master's or doctoral degrees in computer science, information systems or a related field. Many of them held administrative posts thereby decreasing their instructional load. They are both Saudis and non-Saudis where most Ph.D. holders graduated from Western institutions and were Saudi citizens. Some of the faculty taught males only while others taught both males and females. Classes in Saudi Arabia are gender-segregated, and all of the courses taught for this study were online. Most instructors participating in the study taught asynchronously during the period of the research.

\subsection{Data Collection}

A newly developed tool measuring faculty engagement was constructed. Table 1 demonstrates the items, their validity and reliability metrics. The instrument measures four dimensions comprising faculty's engagement in higher education: the use of relevant emotional content, exemplifying excellent performance, the utilization of community building strategies and storytelling. Each construct is measured by five items. Each item is a Likert-type statement the observer rates the lecture. The five possible measurement categories are: $1=$ Not at all, $2=$ Seldom, $3=$ Few Times, $4=$ Frequent and $5=$ Always A summated scale per construct is constructed by summing scores on the five items per construct to yield a scale ranging from 5 to 25 . Then, a dichotomous variable is created from the constructed scale, $0=12$ or less (not engaged) and $1=$ more than 12 (engaged). Notice that the scales, as well as the entire instrument, possess Cronbach alphas of larger than 0.70 indicating adequate reliability for research purposes. Similarly, each corrected-item total correlation exceeds 0.30 indicating the item's stability, as well as convergent validity. This correlation represents the association between the item and the total score with the entire instrument. Notice that the values of corrected-item-total correlation for the item and its respective construct are larger than 0.30 (unshown for brevity) suggesting further evidence of reliability and validity. Table 2 shows the bivariate correlations between the constructed scales in the instrument indicating that all associations are less than 0.50 indicating acceptable evidence of discriminant validity. 
Table 1 . The items, their validity and reliability metrics.

\begin{tabular}{|c|c|c|c|}
\hline Item & $\begin{array}{l}\text { Factor } \\
\text { Loading }\end{array}$ & $\begin{array}{l}\text { Corrected-Item } \\
\text { Total Correlation }\end{array}$ & $\begin{array}{l}\text { Cronbach's } \\
\text { Alpha }\end{array}$ \\
\hline Use of Relevant Emotional Content & & & 0.79 \\
\hline $\begin{array}{l}\text { EM1: The instructor uses emotional hooks, songs, provocative questions, news } \\
\text { headlines or similar relevant content to introduce topic/subtopics. }\end{array}$ & 0.73 & 0.42 & \\
\hline $\begin{array}{l}\text { EM2: The instructor uses relevant assignments, tasks and projects for students' } \\
\text { daily lives or contemporary social/cultural events/content. }\end{array}$ & 0.64 & 0.40 & \\
\hline $\begin{array}{l}\text { EM3: The instructor interrupts the routine with an emotional } \\
\text { appeal/plea/message at least once during the class session. }\end{array}$ & 0.62 & 0.38 & \\
\hline EM4: The instructor incorporates humor into materials/class content. & 0.60 & 0.34 & \\
\hline $\begin{array}{l}\text { EM5: The instructor encourages students to share their emotions in connection } \\
\text { to class discussions/content. }\end{array}$ & 0.59 & 0.33 & \\
\hline Exemplary Performance & & & 0.76 \\
\hline $\begin{array}{l}\text { PER1: The instructor exhibits great public speaking abilities avoiding } \\
\text { um or ah. }\end{array}$ & 0.82 & 0.42 & \\
\hline PER2: The instructor uses variable tones avoiding a constant monotonic style. & 0.76 & 0.41 & \\
\hline $\begin{array}{l}\text { PER3: The instructor introduces new material/activities/group-based tasks } \\
\text { unplanned in the syllabus or expected by students. }\end{array}$ & 0.73 & 0.39 & \\
\hline $\begin{array}{l}\text { PER4: The instructor is awake, active and attentive to students' } \\
\text { questions/requests throughout the session. }\end{array}$ & 0.71 & 0.36 & \\
\hline PER5: The instructor exhibits an excellent public speaking ability. & 0.67 & 0.34 & \\
\hline Community Building & & & 0.78 \\
\hline CB1: The instructor knows his/her students' names. & 0.83 & 0.48 & \\
\hline $\begin{array}{l}\text { CB2: The instructor utilizes small-group discussions as a regular method for } \\
\text { in-class collaboration. }\end{array}$ & 0.79 & 0.45 & \\
\hline $\begin{array}{l}\text { CB3: The instructor makes an effort to encourage every student to participate } \\
\text { and ensure that every student is heard. }\end{array}$ & 0.74 & 0.42 & \\
\hline $\begin{array}{l}\text { CB4: The instructor works with a class on a shared } \\
\text { project/task/question solution. }\end{array}$ & 0.70 & 0.38 & \\
\hline $\begin{array}{l}\text { CB5: The instructor diversifies instructional strategies to meet all } \\
\text { learning styles. }\end{array}$ & 0.67 & 0.35 & \\
\hline Digitized Storytelling & & & 0.73 \\
\hline $\begin{array}{l}\text { DS1: The instructor shares detailed personal stories about him/herself to } \\
\text { stimulate students' interest. }\end{array}$ & 0.79 & 0.42 & \\
\hline $\begin{array}{l}\text { DS2: The instructor shares stories about scientists, scholars and field } \\
\text { development with sufficient detail. }\end{array}$ & 0.75 & 0.39 & \\
\hline $\begin{array}{l}\text { DB3: The instructor creates a story about the progress/development of } \\
\text { the class. }\end{array}$ & 0.71 & 0.38 & \\
\hline $\begin{array}{l}\text { DB4: The instructor encourages students to share their own stories relevant to } \\
\text { the class. }\end{array}$ & 0.65 & 0.33 & \\
\hline $\begin{array}{l}\text { DB5: The instructor asks students to reflect and celebrate their learning by } \\
\text { sharing their stories. }\end{array}$ & 0.63 & 0.32 & \\
\hline
\end{tabular}

Table 2. Inter-item correlation.

\begin{tabular}{ccccc}
\hline Construct & Emotional Use 1 & Performance 2 & Community Building 3 & Storytelling \\
\hline 1 & 1.00 & & & \\
2 & 0.31 & 1.00 & & \\
3 & 0.29 & 0.42 & 1.00 & 1.00 \\
4 & 0.43 & 0.46 & 0.49 & \\
\hline
\end{tabular}

Student engagement was assessed on three items: cognitive, behavioral and affective. Observers rated students on whether they invested cognitive resources in learning the material during the classroom or not, actively participated in any given opportunity to voice their responses, feedback or skills and indicated a positive emotional tone towards learning and their class. Each item was measured dichotomously, $0=$ students did not 
exhibit the feature and $1=$ students exhibited the feature. Once all three measures were recorded, a summated index was made by adding scores on the three items constructing a global students' engagement item. Table 3 demonstrates the correlations between the three students' engagement constructs and the global engagement measure. Note that all of them are highly correlated, larger than 0.60 , indicating that they all measure students' engagement, valid.

Table 3. Correlations between the three students' engagement.

\begin{tabular}{ccccc}
\hline Construct & $\begin{array}{c}\text { Cognitive } \\
\text { Engagement 1 }\end{array}$ & $\begin{array}{c}\text { Behavioral } \\
\text { Engagement 2 }\end{array}$ & $\begin{array}{c}\text { Affective } \\
\text { Engagement 3 }\end{array}$ & $\begin{array}{c}\text { Global } \\
\text { Engagement 4 }\end{array}$ \\
\hline 1 & 1.00 & & & \\
2 & 0.63 & 1.00 & & \\
3 & 0.65 & 0.68 & 1.00 & 1.00 \\
4 & 0.73 & 0.71 & 0.65 & \\
\hline
\end{tabular}

\subsection{Procedures}

Four faculty were recruited to rate faculty and student engagement using the developed measures. Once informed consent was obtained from all participating faculty, four lectures were retrieved from Blackboard to be rated on the measurement instrument. Each rater independently observed the four lectures and rendered his scores. Prior to the rating procedure, the raters and the researchers met to clarify any concerns, questions, or misconceptions regarding the rating procedure. Once all points were cleared, the raters spent one week listening to recorded lectures and rating them. To ensure consistency of ratings, an inter-rater reliability examination was performed (Table 4) by correlating the four rater's scores yielding high correlations, larger than 0.90 indicating high consistency.

Table 4. Inter-rater reliability.

\begin{tabular}{ccccc}
\hline Construct & Rater $\mathbf{1}$ & Rater $\mathbf{2}$ & Rater 3 & Rater 4 \\
\hline 1 & 1.00 & & & \\
2 & 0.93 & 1.00 & & \\
3 & 0.91 & 0.91 & 1.00 & 1.00 \\
4 & 0.90 & 0.92 & 0.94 & \\
\hline
\end{tabular}

Prior to the rating procedure, a training session where the researchers demonstrated how the instrument is used to measure faculty engagement, as well as students' engagement in two lectures was demonstrated. The lecture was played in its entirety once before the rating procedure took place. A general idea about whether the faculty engaged in the four dimensions or not was noted. Then, the lecture was played a second time where the rater went through the instrument item by item and assigned a score according to his observation. The rating procedure took about $3 \mathrm{~h}$ per lecture, which lasted anywhere between 30 and $45 \mathrm{~min}$. The rating was performed in each rater's campus office over a period of one week. All raters are fluent Arabic and English speakers allowing them to assess the level of engagement in both languages given that the content of the material is in English while the spoken language by many faculty members was Arabic. The rating instrument was in English, and all raters demonstrated a clear understanding of the items and their wordings.

All raters used an online Qualtrics link to record their responses. Raters were not given written content on how to rate since they watched pre-recorded training on how to respond to all items on the engagement instrument. All raters used their personal computers and laptops. Notice that students did not rate their experiences, and the four faculty completed all the ratings for their peers' engagement, as well as their students' engagement. 


\subsection{Data Analysis}

A variety of descriptive and inferential statistical techniques were used to analyze the collected data in SPSS Version 26. First, simple means' comparisons on the four measures of faculty engagement were displayed based on demographic and work experience characteristics of faculty. Second, correlational analysis was performed to discern the magnitude and direction of relationships between the different constructs measuring faculty engagement, and students' engagement. Third, logistic regression analysis was used to model the relationship between faculty engagement and students' engagement.

In the simple means' comparison stage, the means of emotional instruction/content use, exemplary performance traits, community building strategies and storytelling (measures of faculty engagement) were computed. For different demographic groups to detect any practical significant difference. The means were calculated for the instructors' gender, course load, held a doctoral degree or not, work experience and whether the degree was awarded by a Western or non-Western institution. In addition, the means of the four dimensions of faculty engagement were computed based on whether their students were engaged or not during their lectures. This helps determine whether faculty who exhibited all or some engagement practices exhibited significant differences with respect to students engagement dimensions: cognitive, affective and behavioral.

Correlation analysis was performed by calculating the Pearson product correlation (r) between faculty engagement and students' engagement. Correlations between the four dimensions of faculty engagement, and the three facets of students' engagement were computed. This helps in discerning the most influential dimensions of faculty engagement that drive changes in students' engagement in computer science e-learning environments. Correlations inform the reader about the proportion of variance explained by each variable with respect to the other if squared. This assists in determining the most important faculty engagement dimension for each different facet of students' engagement.

Logistic regression analysis was utilized to model the relationship between faculty engagement and students' engagement. A total of four models were specified and performed. The dependent variables were all coded into 0 (absence of student engagement) and 1 (presence of students engagement). Each model utilized a different dependent variable corresponding to the three student engagement dimensions, and their summated scale is referred to as global engagement. The independent variables for the four models were all the same: age, gender, whether the instructor was educated in the West or not, the course load per instructor, years of experience, instructors' emotional instruction use, instructors' use of exemplary performance traits, instructors' utilization of community building strategies and instructors' deployment of storytelling while teaching. Odds ratios were calculated per independent variable to discern the explanatory power of each variable on students' engagement outcomes. Figure 1 shows the method of the research. 


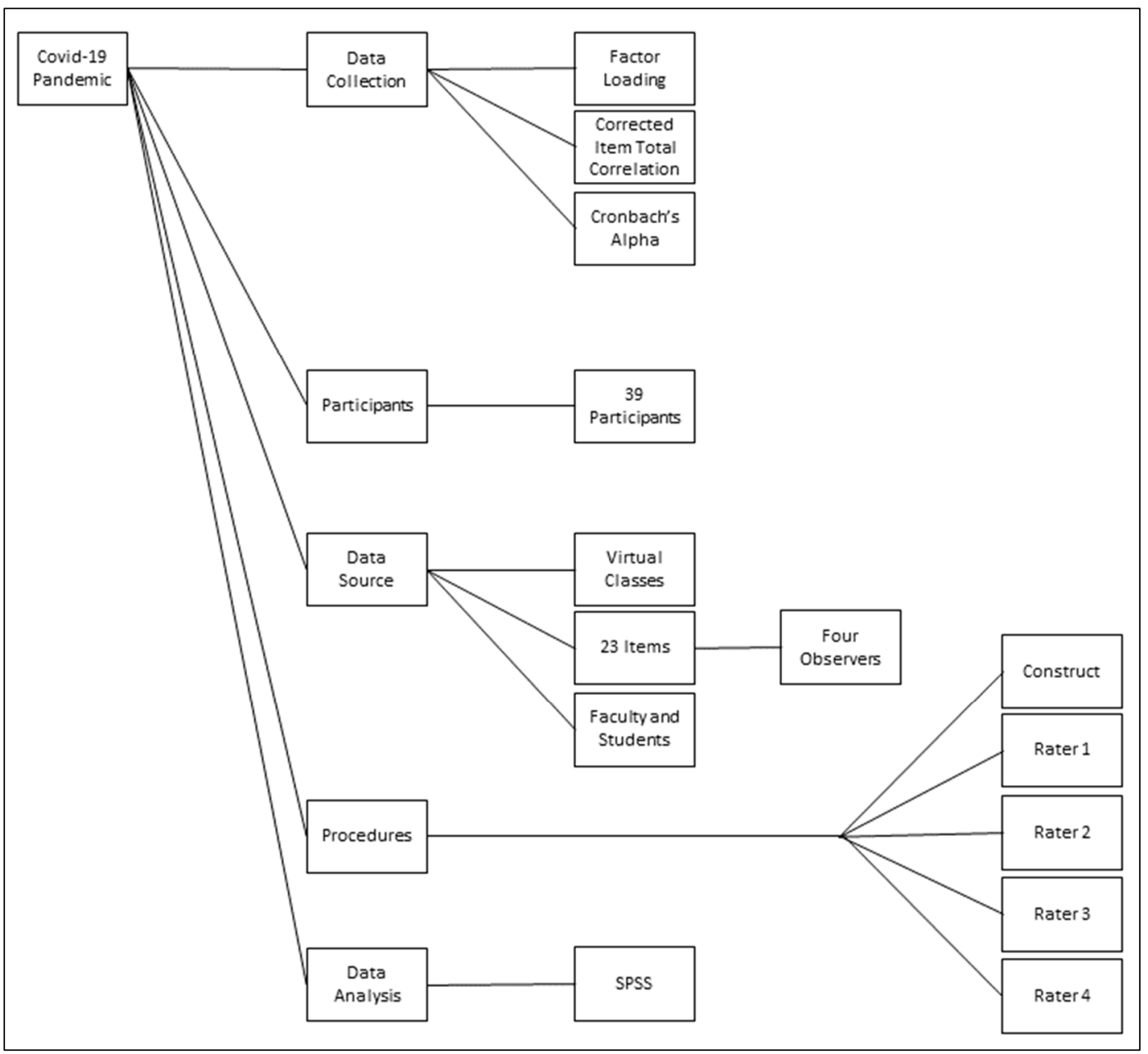

Figure 1. Methods of the research.

\section{Results}

Table 5 and Figure 2 demonstrate the means on the four dimensions of faculty engagement contingent on educational and work characteristics. The first row in Table 5 displays the means of emotional strategies used by computer science/information systems faculty at Najran University during the COVID-19 e-learning semester. Note that none of the means is above 3 on a scale ranging from 1 to 5 indicating a low use of emotional content, instruction or teaching. Faculty with doctoral degrees who are educated in the West exhibited the highest level of emotional use strategies. Similarly, lecturers with master's degrees from non-Western universities demonstrated the lowest levels of emotional strategies utilization. Notice that the differences are not large suggesting the general absence of emotionally informed instructional techniques.

The second row in Table 5 shows the means of community building strategies used by faculty at Najran University during the COVID-19 virtual term. A general pattern of low to moderate utilization of collaborative, cooperative and shared instructional, teaching and assessment techniques is observed. Faculty with Ph.D. degrees from Western institutions emerged as the highest group who employed community building techniques more than others. Many of the means' differences, however, are small. This observation notes the low utilization rates of shared classroom activities, objectives and assignments by the faculty.

The third row in Table 5 showcases the means of digital storytelling utilization by faculty at Najran University's computer science/information systems departments during COVID-19 online learning. Note that most means are below 3, indicating a low utilization of digital storytelling techniques throughout virtual lectures. Ph.D. holders who graduated 
from Western universities and colleges exhibited the highest level of digital storytelling. Lectures without doctoral degrees who obtained their diplomas from non-Western institutions demonstrated the lowest use of digital storytelling. The general theme across the departments is that faculty do not utilize storytelling as a main technique in their online teaching.

Table 5. The means of constructs exhibited by computer science/information systems faculty at Najran university during the COVID-19 online semester.

\begin{tabular}{ccccccccccc}
\hline Means & PhDs & $\begin{array}{c}\text { Non- } \\
\text { PhDs }\end{array}$ & $\begin{array}{c}\text { Less Than } \\
\text { 3 Years } \\
\text { Teaching }\end{array}$ & $\begin{array}{c}\text { 3 or More } \\
\text { Years } \\
\text { Teaching }\end{array}$ & $\begin{array}{c}\text { Less Than } \\
\text { 3 Courses }\end{array}$ & $\begin{array}{c}\text { 3 Courses } \\
\text { or More }\end{array}$ & $\begin{array}{c}\text { West } \\
\text { Educated }\end{array}$ & $\begin{array}{c}\text { Non-West } \\
\text { Educated }\end{array}$ & $\begin{array}{c}\text { Males } \\
\text { Females }\end{array}$ \\
\hline $\begin{array}{c}\text { Emotional } \\
\text { Content Use }\end{array}$ & 2.65 & 1.91 & 2.22 & 2.65 & 2.12 & 2.35 & 2.91 & 1.68 & 2.15 & 2.49 \\
$\begin{array}{c}\text { Community } \\
\text { Building }\end{array}$ & 2.65 & 1.72 & 1.86 & 1.90 & 2.16 & 1.65 & 2.32 & 1.69 & 1.78 & 1.67 \\
$\begin{array}{c}\text { Storytelling } \\
\text { Performance }\end{array}$ & 2.91 & 2.18 & 1.85 & 2.39 & 2.70 & 2.61 & 2.81 & 2.90 & 2.38 & 2.55 \\
\hline
\end{tabular}

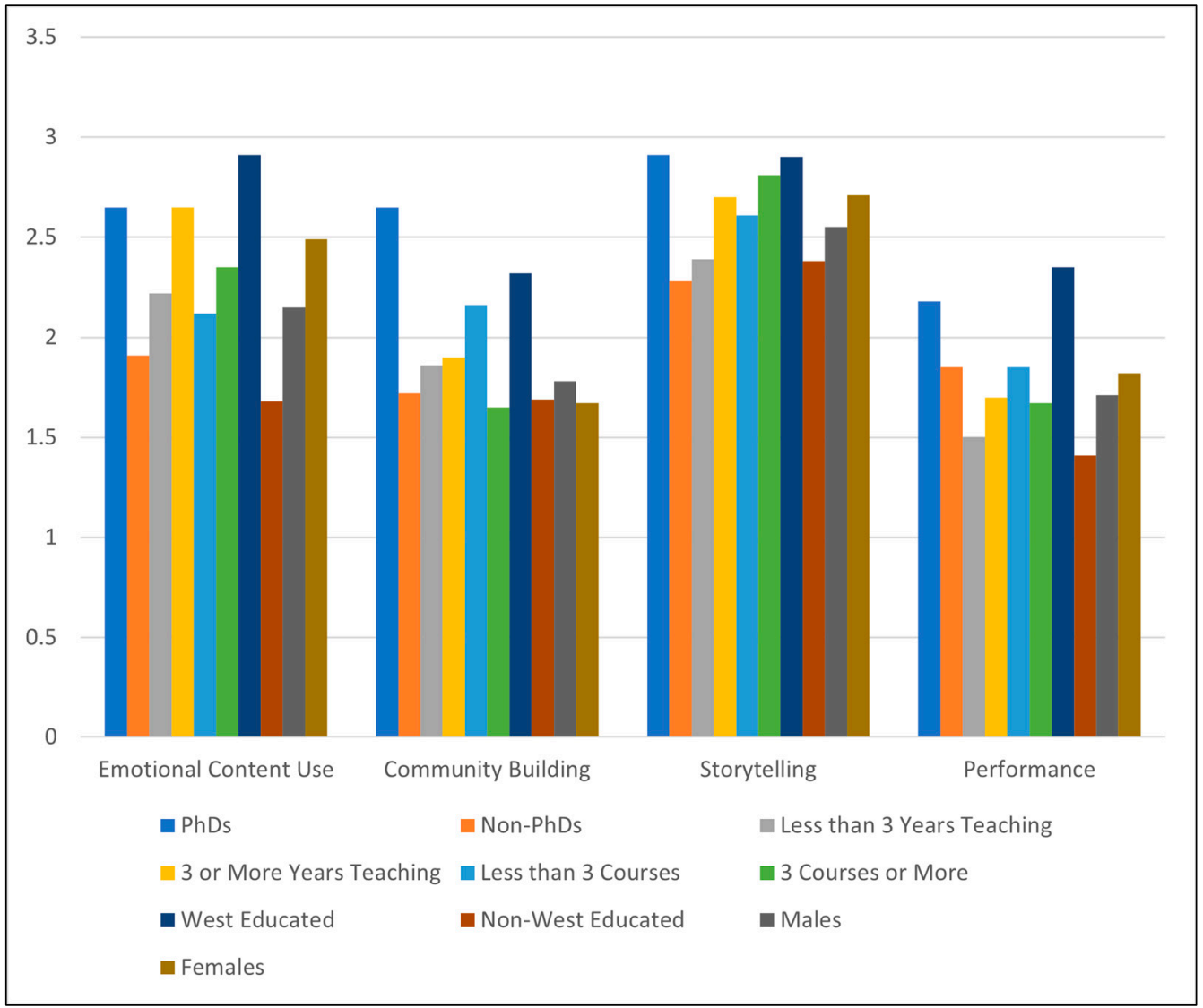

Figure 2. Grouped means of the constructs in Table 5.

The fourth row in Table 5 shows the means of performance abilities exhibited by computer science/information systems faculty at Najran University during the COVID-19 online semester. A trend of low means emerges across all sub-groups. The best performing groups were Ph.D. holders from the West who teach a relatively low course load. By contrast, faculty who only possess master's degrees from non-Western institutions that teach more than three courses exhibited the lowest performance metrics during their lectures. Overall, many of the means' differences are negligible noting a general lack of exemplary performance skills by the faculty. 
Table 6 displays the means of the four faculty engagement practices by students' engagement measures. For faculty who were deemed to have cognitively, affectively and behaviorally engaged students, they exhibited higher means of emotional content/instruction use, performance abilities, community building strategies utilization and digital storytelling practice. Performance seems to generate higher means of engagement across all measures compared to emotional content/instruction use, community building practices and digital storytelling utilization. Means differences between faculty who generated engaged students and those who did not were large and significant.

Table 6. Simple comparison of means of the four faculty engagement practices by students' engagement measures.

\begin{tabular}{|c|c|c|c|c|}
\hline & Emotional Content Use & Performance & Community Building & Storytelling \\
\hline $\begin{array}{l}\text { Cognitive Engagement } \\
\text { Engaged }=1 \\
\text { Not Engaged }=0\end{array}$ & $\begin{array}{l}3.40 \\
1.80\end{array}$ & $\begin{array}{l}3.75 \\
1.20\end{array}$ & $\begin{array}{l}2.30 \\
1.40\end{array}$ & $\begin{array}{l}2.60 \\
1.80\end{array}$ \\
\hline $\begin{array}{l}\text { Behavioral Engagement } \\
\text { Engaged }=1 \\
\text { Not Engaged }=0\end{array}$ & $\begin{array}{l}3.25 \\
1.60\end{array}$ & $\begin{array}{l}3.60 \\
1.50\end{array}$ & $\begin{array}{l}2.65 \\
1.70\end{array}$ & $\begin{array}{l}2.90 \\
1.70\end{array}$ \\
\hline $\begin{array}{l}\text { Affective Engagement } \\
\text { Engaged }=1 \\
\text { Not Engaged }=0\end{array}$ & $\begin{array}{l}3.10 \\
1.40\end{array}$ & $\begin{array}{l}3.50 \\
1.70\end{array}$ & $\begin{array}{l}2.25 \\
1.36\end{array}$ & $\begin{array}{l}2.75 \\
1.60\end{array}$ \\
\hline $\begin{array}{l}\text { Global Engagement } \\
\text { Engaged }=1 \\
\text { Not Engaged }=0\end{array}$ & $\begin{array}{l}3.25 \\
1.60\end{array}$ & $\begin{array}{l}3.70 \\
1.30\end{array}$ & $\begin{array}{l}2.40 \\
1.60\end{array}$ & $\begin{array}{l}2.60 \\
1.45\end{array}$ \\
\hline
\end{tabular}

Table 7 and Figure 3 show the bivariate correlations between measures of faculty engagement and student engagement. Performance is the strongest covariate for all students. engagement measures compared to other faculty engagement variables. Storytelling is the second-best predictor of student engagement. Community-building strategies and emotional content/instruction use possess similar low to moderate effects on students' engagement. Notwithstanding the different magnitudes of associations, all faculty engagement measures positively increase student engagement across all its measures in non-negligible terms.

Table 7. Correlations between measures of faculty engagement and student engagement.

\begin{tabular}{ccccc}
\hline & $\begin{array}{c}\text { Emotional } \\
\text { Content Use }\end{array}$ & Performance & $\begin{array}{c}\text { Community } \\
\text { Building }\end{array}$ & Storytelling \\
\hline Cognitive Engagement & 0.32 & 0.51 & 0.24 & 0.35 \\
Behavioral Engagement & 0.34 & 0.47 & 0.31 & 0.38 \\
Affective Engagement & 0.26 & 0.53 & 0.29 & 0.32 \\
Global Engagement & 0.27 & 0.55 & 0.28 & 0.34 \\
\hline
\end{tabular}

Table 8 displays the logistic regression results for four models assessing the degree to which faculty engagement influences students' engagement in computer science/information systems virtual classrooms at Najran University. Model 1 uses cognitive engagement as the outcome and 10 predictors. Note that the odds of students being cognitively, behaviorally, affectively and generally engaged in the classroom increase at rates of 2.34, 2.81, 2.83 and 2.74 respectively when faculty are deemed to utilize emotional content/instruction. By the same token, students' odds of being engaged cognitively, behaviorally, affectively and generally increase at rates of 3.21, 3.35, 3.68 and 3.31 when faculty are determined to exhibit exemplary performance abilities. Similarly, students' odds of being cognitively, behaviorally, affectively and generally engaged increase by factors of 2.14, 2.32. 2.41 and 2.28 when faculty use community building strategies in their lectures. 
Finally, students' odds of being cognitively, behaviorally, affectively and generally increase at rates of 2.32, 2.42, 2.31 and 2.23 if faculty utilize digital storytelling in their online sessions. All odds ratios were statistically significant at the 0.01 level. All four models explained a sizable portion of the variance in all four measures of students' engagement as indicated by the moderate Cox and Snell's R squares.

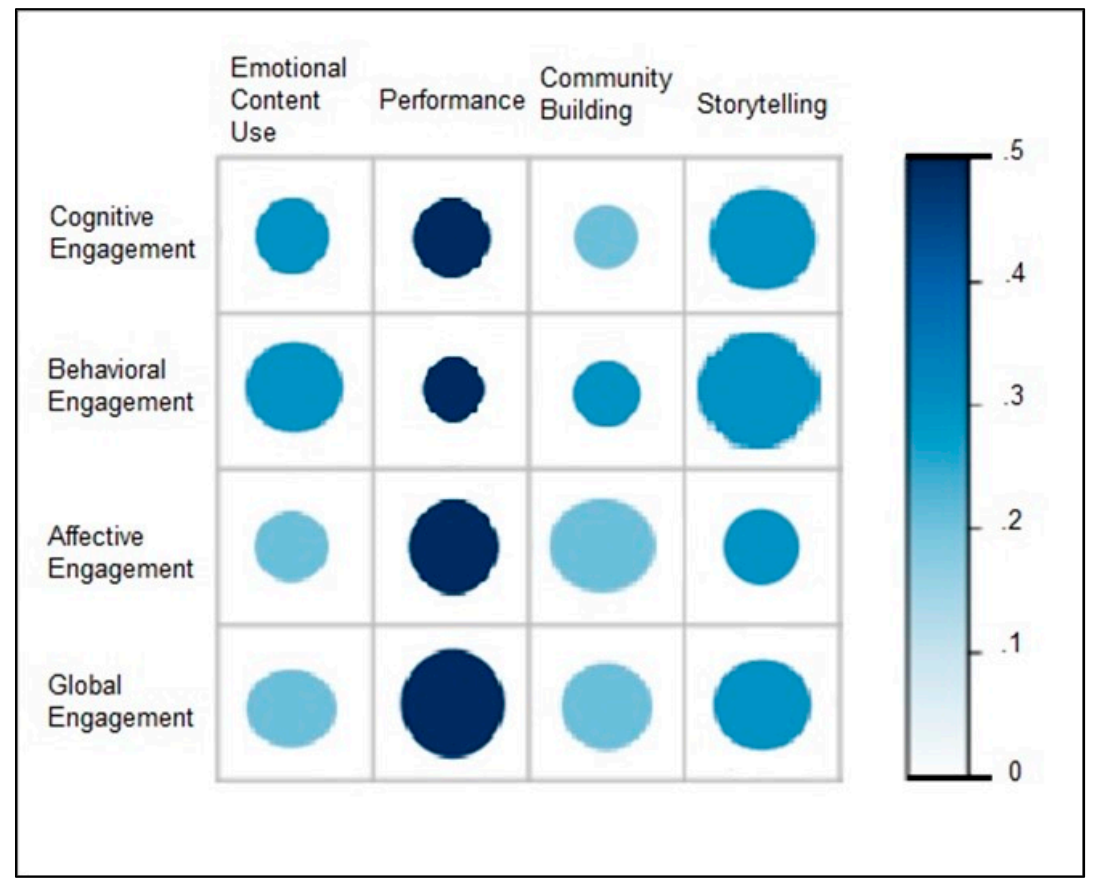

Figure 3. Correlation plot of faculty engagement and student engagement.

Table 8. Logistic regression results.

\begin{tabular}{|c|c|c|c|c|c|c|c|c|}
\hline \multirow{2}{*}{$\begin{array}{l}\text { Variables } \\
\text { Estimates }\end{array}$} & \multicolumn{2}{|c|}{$\begin{array}{c}\text { Model } 1 \\
\text { (Cognitive Engagement) }\end{array}$} & \multicolumn{2}{|c|}{$\begin{array}{c}\text { Model } 2 \\
\text { (Behavioral Engagement) }\end{array}$} & \multicolumn{2}{|c|}{$\begin{array}{c}\text { Model } 3 \\
\text { (Affective Engagement) }\end{array}$} & \multicolumn{2}{|c|}{$\begin{array}{c}\text { Model } 4 \\
\text { (Global Engagement) }\end{array}$} \\
\hline & OR & $\mathrm{P}$ & OR & $\mathrm{P}$ & OR & $\mathrm{P}$ & OR & $\mathrm{P}$ \\
\hline Age & 1.21 & 0.08 & 1.14 & 0.11 & 1.14 & 0.09 & 1.09 & 0.13 \\
\hline Years of Experience & 1.56 & 0.04 & 1.38 & 0.05 & 1.41 & 0.02 & 1.33 & 0.03 \\
\hline Gender & 1.04 & 0.21 & 1.09 & 0.26 & 1.07 & 0.35 & 1.09 & 0.23 \\
\hline $\mathrm{PhD}$ & 1.89 & 0.02 & 1.78 & 0.03 & 1.92 & 0.01 & 1.82 & 0.02 \\
\hline West & 1.71 & 0.03 & 1.62 & 0.04 & 1.69 & 0.03 & 1.81 & 0.02 \\
\hline Course load & 1.19 & 0.08 & 1.12 & 0.06 & 1.16 & 0.13 & 1.09 & 0.08 \\
\hline Emotional Content Use & 2.34 & 0.01 & 2.81 & 0.01 & 2.83 & 0.01 & 2.74 & 0.01 \\
\hline Performance & 3.21 & 0.01 & 3.35 & 0.01 & 3.68 & 0.01 & 3.31 & 0.01 \\
\hline Community Building & 2.14 & 0.01 & 2.32 & 0.01 & 2.41 & 0.01 & 2.28 & 0.01 \\
\hline Digital Storytelling & 2.32 & 0.01 & 2.42 & 0.01 & 2.31 & 0.01 & 2.23 & 0.01 \\
\hline Cox and Snell's R Square & \multicolumn{2}{|c|}{0.28} & \multicolumn{2}{|c|}{0.31} & \multicolumn{2}{|c|}{0.33} & \multicolumn{2}{|c|}{0.39} \\
\hline
\end{tabular}

The logistic regression analysis lent support to some characteristics of faculty in increasing student engagement. First, obtaining a doctoral degree from a Western university or college in the US, UK, Australia, Canada, or New Zealand was associated with a modest increase in the odds of being engaged for students across all measures. By contrast, age, gender, course load or years of teaching experience did not contribute to the odds of students' engagement in virtual lectures at Najran University.

\section{Discussion}

The findings of this analysis confirm earlier results establishing a strong link between faculty engagement and student engagement. First, making instruction more social and emotional is found to increase students' motivation to learn, be more satisfied with the course and invest more time in learning the material. Second, exemplary performance by 
faculty instigate students' interest in the material and makes many of them decide to join the major hoping to become like their faculty. Third, collaborative learning is proven to assist many students, especially those needing the most help to retain an interest in learning and develop new knowledge and skills acquired through the class. Fourth, students' cognitive resources are more activated when the material introduced to them is lively and relevant presented in stories/narratives formats.

While a direct measure of academic performance or knowledge retention was not considered in this research, a global measure of students' engagement was taken. Past researchers have indicated a consistent positive relationship between academic performance, knowledge retention, and engagement across countries, disciplines, and contexts. Figure 4 displays the effects of faculty engagement on students' overall performance measured by multi-dimensional engagement. On the left, R-squared per each construct was estimated to investigate the proportion of variance explained by each dimension. Faculty performance in the classroom explains about thirty percent of the variation in students' performance measured by their global engagement throughout the semester. To a lesser extent, emotional content use, storytelling, and community-building practices account for anywhere between ten to fifteen percent each in the variance of performance among students. This result is corroborated by the odds ratios from model 4 for each of the constructs. The effects of faculty performance are stronger compared to the other three types of faculty engagement on students' performance. This leads to the conclusion that faculty who are more charismatic, emotionally intelligent, socially engaging, and humorous in their classrooms generate better academic performance and engagement for their students.

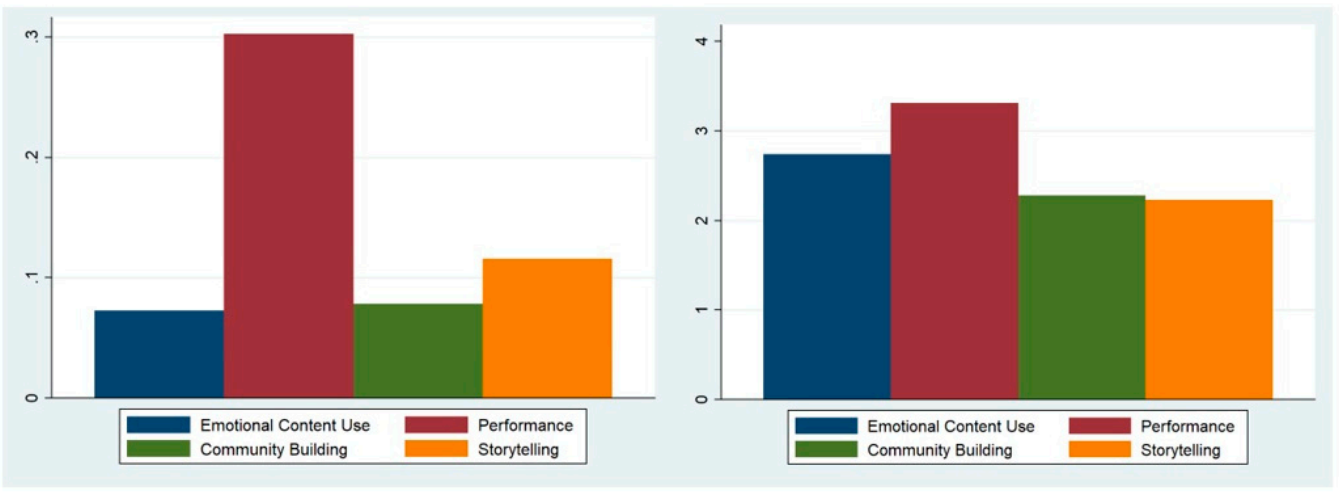

Figure 4. R-Squared (Left) and Odds-Ratio (Right) Values.

\subsection{Recommendations}

The study reported low faculty engagement ratings calling for immediate interventions to make instruction more interesting, attractive, lively, and accessible to students. One of the best available solutions addressing the deficiency in faculty engagement is professional development programs. New faculty should be mandated to complete several simulations demonstrating their mastery of exemplary instruction. Tenured faculty needs to undergo ongoing regular audits for their teaching ensuring high compliance with recommended instructional strategies. Students should be consulted regularly through focus groups and surveys on whether they perceived the faculty's teaching as engaging or not.

Tenure promotion committees need to emphasize the significance of exemplary instruction in promotion decisions. Faculty need to be given clear criteria and measurements of what is expected from them when they teach in the classroom. Centers for Teaching and Learning need to be involved in the promotion process where an expert helps the committee draft an individualized teaching plan highlighting an area of strength and weaknesses to be given to the faculty every year guiding their instructional practice. The bulk of what faculty do in Saudi Arabia is teaching, and therefore it should be the most important element in tenure-promotion processes. 
Saudi universities need to invest in the Centers for Teaching and Learning. Many faculty graduate from Western and non-Western institutions without having to teach a single course. Many computer sciences/information systems faculty did not take courses in instruction or teaching effectiveness. There is a pressing need to funnel more resources into teaching and learning across Saudi colleges and universities. Authentic simulations in Arabic and English demonstrating exemplary teaching in the classroom need to be developed and disseminated across all faculty ranks. Departments, colleges, and tenure committees need to stress the significance of exemplary engaging instruction in recruitment, retention and promotion policies and procedures.

\subsection{Practical Implications}

Faculty teaching online classes during COVID-19 should consult available validated guides on making their instruction more engaging. Many centers for teaching and learning offer workshops on making teaching livelier and more effective. Faculty need to complete a series of training sessions prior to posting their lectures online. In addition, many online resources are available to faculty through the Chronicle of Higher Education, Inside Higher $E d$, and other popular outlets on higher education affairs. Faculty need to solicit the assistance of their colleagues in observing their lectures and identifying areas for improvement. Faculty engagement is a continuous improvement process where new and tenured professors need regular coaching and enhancement.

E-learning divisions, deanships and departments need to develop model simulationbased workshops demonstrating excellent teaching strategies and disseminate them to all faculty. Simulation-based learning serves as an appropriate method of instruction for faculty engagement since it shows how the faculty are expected to perform while teaching. Faculty are encouraged to videotape themselves once they observe the exemplary instruction sessions and share them with an e-learning committee composed of faculty who won teaching excellence awards in their respective institutions for feedback. All faculty teaching online regardless of their ranks or positions should be mandated to perform this activity to ensure instructional quality.

The Ministry of Education in Saudi Arabia is encouraged to form a faculty engagement assessment committee tasked with monitoring and enforcing exemplary teaching at all institutions. The committee shall produce exemplary guides and videography on every aspect of engaging instruction. This material should be disseminated across all higher learning institutions. Regular audits should take place ensuring that institutions are keeping in line with the mandated guidelines of faculty engagement.

\subsection{Theoretical Contributions}

This study lends support to the engagement theoretical framework spelled by Kearsley and Shneiderman [114] in explaining distance education outcomes. The underlying principle is that learning occurs in collaborative activities that are meaningful, and purposeful. This collaboration is facilitated by the use of e-learning technologies. The current study documented the elevated cognitive, affective and behavioral engagement of students in courses featuring high collaboration, community building activities and small groups activities facilitated carefully by interactive and timely intervening instruction. This prescription defies the general negative connotation associated with e-learning. On the contrary, the current manuscript demonstrates that, if designed carefully, e-learning programs are capable of producing engaged classrooms.

On another theoretical front, this manuscript supports the flow theory of student engagement [87]. This explanation emphasizes the role of interest, enjoyment and concentration in enhancing students' engagement throughout the course. Instructors who captured the interest of students through storytelling and performance techniques featured more concentration, as well as interest in their classrooms. Instructors who utilized empathetic instruction coupled with community-building strategies also increased the three wheels of engagement making students more invested in the learning process. 
This research supports educators' best practices models proposed to increase students engagement in higher education. Evidence-based practices like the enabling of social capital, unifying institutional culture, constitute community-building strategies that prove to increase students' engagement at all levels in e-learning environments. In addition, designing learning to prepare students to become active citizens, using relevant enriching emotional instruction and providing empathetic support constitutes the incorporation of the instructor's emotional learning dimensions that have been positively associated with students' engagement. Adaptation to changing environments and expectations, modeling leadership traits and the creation of interactive collaborative learning experiences are exemplary attributes of excellent performers that have been shown to increase engagement. The use of provocative and attention-grabbing stories, letting students share their own experiences and construct their own understandings while working with classmates and allowing students to prescribe their own feelings and ideas are all characteristics of storytelling that all increase engagement in classrooms. This research confirms the empirical validity of the best practices of students' engagement in higher education.

\subsection{Future Research}

Researchers are urged to disaggregate faculty engagement, as well as students' engagement in their future research. They are cautioned that survey-based research, as well as observational evidence, may suffer from several biases, and therefore should focus efforts on experimental studies. Interventions need to be designed and validated using sufficient sample sizes, institutional variation and across a plethora of disciplines. Also, the need to formulate short, effective and efficient professional development programs in Arabic for faculty teaching in majority-Arabic speaking countries needs to be emphasized by the research community in the Middle East and North Africa.

\subsection{Limitations}

There are many limitations to the current study. Its study are based on cross-sectional data from a single institution within one college. This weakens the generalizability and external validity of the inferences put forward by the authors. In addition, the number of lectures considered in making the conclusions of the analysis is small. The material in computer science and information systems is drier compared to other departments like the social sciences and humanities making it less engaging. The measurement tool for faculty engagement, while reliable and valid, is new and its use is prone to generating a larger degree of measurement error. The rater went through a well-thought training; however, their individual variation may have potentially caused some differences in scoring the items. The study took place in an e-learning environment making instruction by definition less engaging.

\section{Conclusions}

This study presented evidence linking faculty engagement to improved students' outcomes in computer science courses taught online. Positive consistent significant associations between faculty's use of emotional and empathetic content, an exhibition of exemplary performance traits, deployment of storytelling techniques, use of community building strategies and students' engagement outcomes were reported. The psychometric properties of a new instrument measuring Saudi faculty's engagement were displayed suggesting adequate reliability and validity metrics for research purposes. The exercise of strong performance in the classroom, charismatic and transformational leaders' attributes, by faculty yielded the best students' engagement outcomes.

This research has supported existing students' engagement theories and indicated the need to blend them for use in e-learning environments. On a positive note, the research presents a challenging hallmark for those questioning the quality of e-learning programs during COVID-19. On another spectrum, the research highlights the need for more instructor engagement in computer science classrooms. Training needs to be provided 
by departments and colleges on the best practices, or validated theories of engagement. These include the preparation of instructors in areas of empathetic and emotional teaching, performance and leadership, storytelling and community building strategies.

One of the applications in the science of electronics is its education. Without properly carrying out the teaching and learning processes of electronics, the knowledge, skills, abilities of the field will be lost. Therefore, setting robust best evidenced practices in the science of electronics teaching presents an imminent priority and relevant real to peers to be published in science and engineering journals. The manuscript has presented that faculty in electronics need to embody empathetic teaching, collaborative learning, and charismatic performance to endure the appropriate transfer of knowledge from experts to interested learners like college students.

Author Contributions: Conceptualization, K.R. and M.H.; methodology, M.S.A.R. and Y.A.; software, A.S.; validation, A.S., A.R. and K.R.; formal analysis, M.H. and M.S.A.R.; investigation, K.R.; resources, A.S.; data curation, M.S.A.R.; writing-original draft preparation, K.R. and M.H.; writing-review and editing, A.S. and A.R.; visualization, Y.A.; supervision, A.R.; project administration, M.S.A.R. and A.S.; funding acquisition, K.R. All authors have read and agreed to the published version of the manuscript.

Funding: The authors are thankful to the Deanship of Scientific Research at Najran University for funding this work under the National Research Priorities funding program under code number NU/NRP/SERC/11/16

Conflicts of Interest: The authors declare no conflict of interest.

\section{References}

1. Even with Booms in Student Enrollment, Not Enough Degrees to Keep Up with Jobs in Computer Science. 2017. Available online: https: / /www.insidehighered.com/news/2017/10/27/even-booms-student-enrollment-not-enough-degrees-keep-jobscomputer-science (accessed on 10 September 2020).

2. Beyer, S. Why are women underrepresented in Computer Science? Gender differences in stereotypes, self-efficacy, values, and interests and predictors of future CS course-taking and grades. Comput. Sci. Educ. 2014, 24, 153-192. [CrossRef]

3. Porter, L.; Lee, C.B.; Simon, B. Halving fail rates using peer instruction: A study of four computer science courses. In Proceedings of the 44th ACM Technical Symposium on Computer Science Education (SIGCSE '13), New York, NY, USA, 6-9 March 2013; Association for Computing Machinery: New York, NY, USA, 2013.

4. Wadesango, N.; Machingambi, S. Causes and structural effects of student absenteeism: A case study of three South African Universities. J. Soc. Sci. 2011, 26, 89-97. [CrossRef]

5. Lauwers, T.; Nourbakhsh, I. Designing the finch: Creating a robot aligned to computer science concepts. In Proceedings of the First AAAI Symposium on Educational Advances in Artificial Intelligence, Atlanta, Georgia, 13-14 July 2010.

6. Rovai, A.P.; Downey, J.R. Why some distance education programs fail while others succeed in a global environment. Int. High. Educ. 2010, 13, 141-147. [CrossRef]

7. Webb, R.; Vulliamy, G.; Hämäläinen, S.; Sarja, A.; Kimonen, E.; Nevalainen, R. Pressures, rewards and teacher retention: A comparative study of primary teaching in England and Finland. Scan. J. Educ. Res. 2004, 48, 169-188. [CrossRef]

8. Sturm, D.; Moroh, M. Encouraging Enrollment and Retention of Women in Computer Science Classes. In Proceedings of the Annual National Educational Computing Conference, Boston, MA, USA, 13-15 June 1994.

9. Why Students Consider Leaving Computing. 2017. Available online: https://www.cs.purdue.edu/news/articles/2017/WhyStudents-Leave-Computing.html (accessed on 10 September 2020).

10. Vitores, A.; Gil-Juárez, A. The trouble with 'women in computing': A critical examination of the deployment of research on the gender gap in computer science. J. Gen. Stud. 2016, 25, 666-680. [CrossRef]

11. Washington, A.N.; Burge, L.; Mejias, M.; Jean-Pierre, K.; Knox, Q.A. Improving undergraduate student performance in computer science at historically Black colleges and universities (HBCUs) through industry partnerships. In Proceedings of the 46th ACM Technical Symposium on Computer Science Education, Kansas City, MS, USA, 4-7 March 2015.

12. Appianing, J.; Van Eck, R.N. Gender differences in college students' perceptions of technology-related jobs in computer science. Int. J. Gend. Sci. Technol. 2015, 7, 28-56.

13. Schäfer, A.; Holz, J.; Leonhardt, T.; Schroeder, U.; Brauner, P.; Ziefle, M. From boring to scoring-a collaborative serious game for learning and practicing mathematical logic for computer science education. Comput. Sci. Educ. 2013, 23, 87-111. [CrossRef]

14. Ryoo, J.J.; Margolis, J.; Lee, C.H.; Sandoval, C.D.; Goode, J. Democratizing computer science knowledge: Transforming the face of computer science through public high school education. Learn. Med. Technol. 2013, 38, 161-181. [CrossRef] 
15. Ko, A.J.; Hwa, L.; Davis, K.; Yip, J.C. Informal mentoring of adolescents about computing: Relationships, roles, qualities, and impact. In Proceedings of the 49th ACM Technical Symposium on Computer Science Education, New York, NY, USA, 21-24 February 2018.

16. Scott, A.; Martin, A.; McAlear, F. Enhancing participation in computer science among girls of color: An examination of a preparatory AP computer science intervention. In Moving Students of Color from Consumers to Producers of Technology; Rankin, Y., Thomas, J., Eds.; IGI Global: Hershey, PA, USA, 2017; Volume 1, pp. 62-84.

17. Reza, S.; Baig, M. A study of inverted classroom pedagogy in computer science teaching. Int. J. Res. Stud. Educ. Technol. 2015, 4, 19-30. [CrossRef]

18. Varma, R. Why so few women enroll in computing? Gender and ethnic differences in students' perception. Comput. Sci. Educ. 2010, 20, 301-316. [CrossRef]

19. Colatrella, C. Gender Codes: Why Women Are Leaving Computing. Technol. Cult. 2012, 53, 958-959. [CrossRef]

20. Kumar, J.A.; Bervell, B.; Osman, S. Google classroom: Insights from Malaysian higher education students' and instructors' experiences. Educ. Inf. Technol. 2020, 25, 4175-4195. [CrossRef]

21. Bakheet, E.M.; Gravell, A.M. Flipped Classroom from Computer Science Instructors' Perspectives: A proposed Model. In Proceedings of the 8th International Conference on Educational and Information Technology, New York, NY, USA, 2-4 March 2019.

22. Al-Samarraie, H.; Teng, B.K.; Alzahrani, A.I.; Alalwan, N. E-learning continuance satisfaction in higher education: A unified perspective from instructors and students. Stud. High. Educ. 2018, 43, 2003-2019. [CrossRef]

23. McGee, P.; Windes, D.; Torres, M. Experienced online instructors: Beliefs and preferred supports regarding online teaching. J. Comput. High. Educ. 2017, 29, 331-352. [CrossRef]

24. Freeman, S.; Eddy, S.L.; McDonough, M.; Smith, M.K.; Okoroafor, N.; Jordt, H.; Wenderoth, M.P. Active Learning Increases Student Performance in Science, Engineering, and Mathematics; National Academy of Science: Washington, DC, USA, 2014; Volume 111, pp. 8410-8415.

25. Gill, G.; Holton, C.F. A self-paced introductory programming course. J. Inf. Technol. Educ. Res. 2006, 5, 95-105. [CrossRef]

26. Deek, F.; Kimmel, H.; McHugh, J.A. Pedagogical changes in the delivery of the first-course in computer science: Problem solving, then programming. J. Eng. Educ. 1998, 87, 313-320. [CrossRef]

27. McGivney, V. Staying or Leaving the Course: Non-Completion and Retention of Mature Students in Further and Higher Education; National Institute of Adult Continuing Education: Leicester, UK, 1996.

28. Cutri, R.M.; Mena, J.; Whiting, E.F. Faculty readiness for online crisis teaching: Transitioning to online teaching during the COVID-19 pandemic. Eur. J. Teach. Educ. 2020, 43, 523-541. [CrossRef]

29. Makarchuk, T.A.; Minakov, V.F.; Trofimov, V.V.; Lobanov, O.S.; Demchenko, S.A.; Barabanova, M.I. Quality management of e-learning in information technology management training. In Proceedings of the European Proceedings of Social \& Behavioural Sciences EpSBS, Irkutsk, Russia, 26-28 April 2019.

30. Ibrahim, A.; Cahyani, D.; Nursalim, M.M.; Arsita, M.; Suparman, M.; Indriyani, S. The Analysis of E-Learning Model with Technology of Acceptance Model (TAM) Method in Faculty of Computer Science Sriwijaya University. J. Phys. Conf. Ser. 2019, 1338, 012025. [CrossRef]

31. Chikh, A.; Berkani, L. Communities of practice of e-learning, an innovative learning space for e-learning actors. Procedia-Soc. Behav. Sci. 2010, 2, 5022-5027. [CrossRef]

32. Assareh, A.; Bidokht, M.H. Barriers to e-teaching and e-learning. Procedia Comput. Sci. 2011, 3, 791-795. [CrossRef]

33. Gulatee, Y. An Investigation into Online Teaching and the Delivery of Computer Science Topics: Practice, Content and Environmental Factors. Ph.D. Thesis, Edith Cowan University, Joondalup, Australia, 2010.

34. Abu-Naser, S.S.; Zaqout, I.S.; Abu Ghosh, M.; Atallah, R.R.; Alajrami, E. Predicting student performance using artificial neural network: In the faculty of engineering and information technology. Int. J. Hybrid Inf. Technol. 2015, 8, 221-228.

35. Hoq, M.Z. E-Learning during the Period of Pandemic (COVID-19) in the Kingdom of Saudi Arabia: An Empirical Study. Am. J. Educ. Res. 2020, 8, 457-464.

36. Elgzar, W.T.; Al-Qahtani, A.M.; Elfeki, N.K.; Ibrahim, H.A. COVID-19 Outbreak: Effect of an Educational Intervention Based on Health Belief Model on Nursing Students' Awareness and Health Beliefs at Najran University, Kingdom of Saudi Arabia. Afr. J. Reprod. Health 2020, 24, 78-86. [PubMed]

37. Abdulrahim, H.; Mabrouk, F. COVID-19 and the Digital Transformation of Saudi Higher Education. Asian J. Dis. Educ. 2020, 15, 291-306.

38. Khalil, R.; Mansour, A.E.; Fadda, W.A.; Almisnid, K.; Aldamegh, M.; Al-Nafeesah, A.; Al-Wutayd, O. The sudden transition to synchronized online learning during the COVID-19 pandemic in Saudi Arabia: A qualitative study exploring medical students perspectives. BMC Med. Educ. 2020, 20, 285. [CrossRef]

39. Perez-Poch, A.; López, D. Just-in-time teaching improves engagement and academic results among students at risk of failure in computer science fundamentals. In Proceedings of the IEEE Frontiers in Education Conference (FIE), Indianapolis, IN, USA, 18-21 October 2017; IEEE: Piscataway, NJ, USA, 2017.

40. DeAngelo, L.; Mason, J.; Winters, D. Faculty engagement in mentoring undergraduate students: How institutional environments regulate and promote extra-role behavior. Innov. High. Educ. 2016, 41, 317-332. [CrossRef]

41. Mandernach, B.J.; Barclay, J.; Huslig, S.; Jackson, C. Faculty engagement as a function of instructional mode and employment status. J. Instr. Res. 2016, 4, 159-167. [CrossRef] 
42. Zhang, X.; McInerney, J.; Frechtling, J. Effect of STEM faculty engagement in the math and science partnership program. Sch. Sci. Math. 2011, 111, 274-287. [CrossRef]

43. Ahmed, E.I. An Investigation of Faculty Members' Engagement in Saudi Arabia. J. Educ. Black Sea Reg. 2018, 3, 114-136. [CrossRef]

44. Alsubaie, A.; Jones, K. An overview of the current state of women's leadership in higher education in Saudi Arabia and a proposal for future research directions. Adm. Sci. 2017, 7, 36. [CrossRef]

45. Alshehri, A.; Gutub, S.A.; Ebrahim, M.A.B.; Shafeek, H.; Soliman, M.F.; Abdel-Aziz, M.H. Integration between industry and university: Case study, Faculty of Engineering at Rabigh, Saudi Arabia. Educ. Chem. Eng. 2016, 14, 24-34. [CrossRef]

46. Aboonq, M. Perception of the faculty regarding problem-based learning as an educational approach in Northwestern Saudi Arabia. Saudi Med. J. 2015, 36, 13-29. [CrossRef] [PubMed]

47. Mahdizadeh, H.; Biemans, H.; Mulder, M. Determining factors of the use of e-learning environments by university teachers Comput. Educ. 2008, 51, 142-154. [CrossRef]

48. Harper, S.R.; Quaye, S.J. Making engagement equitable for students in US higher education. In Student Engagement in Higher Education: Theoretical Perspectives and Practical Approaches for Diverse Populations, 2nd ed.; Harper, S.R., Quaye, S.J., Eds.; Routledge: Oxfordshire, UK, 2015; pp. 1-14.

49. Casamayor, A.; Amandi, A.; Campo, M. Intelligent assistance for teachers in collaborative e-learning environments. Comput. Educ. 2009, 53, 1147-1154. [CrossRef]

50. Moule, P.; Ward, R.; Lockyer, L. Issues with e-learning in nursing and health education in the UK: Are new technologies being embraced in the teaching and learning environments? J. Res. Nurs. 2011, 16, 77-90. [CrossRef]

51. Amriani, A.; Aji, A.F.; Utomo, A.Y.; Junus, K.M. An empirical study of gamification impact on e-Learning environment. In Proceedings of the 3rd International Conference on Computer Science and Network Technology, Dalian, China, 21-22 September 2018; IEEE: Piscataway, NJ, USA, 2018.

52. Herrington, J. Authentic e-learning in higher education: Design principles for authentic learning environments and tasks In Proceedings of the World Conference on E-Learning in Corporate, Government, Healthcare, and Higher Education, Honolulu, HI, USA, 13-17 October 2006; Association for the Advancement of Computing in Education (AACE): Waynesville, NC, USA, 2006.

53. Birch, D.; Burnett, B. Bringing academics on board: Encouraging institution-wide diffusion of e-learning environments. Aust. J. Educ. Technol. 2009, 25, 117-134. [CrossRef]

54. Kotzer, S.; Elran, Y. Learning and teaching with Moodle-based E-learning environments, combining learning skills and content in the fields of Math and Science \& Technology. In Proceedings of the 1st Moodle Research Conference, Heraklion, Greece, 14-15 September 2012.

55. Laeeq, K.; Memon, Z.A. An integrated model to enhance virtual learning environments with current social networking perspective Int. J. Emerg. Technol. Learn. 2018, 13, 252-268. [CrossRef]

56. Bond, M.; Buntins, K.; Bedenlier, S.; Zawacki-Richter, O.; Kerres, M. Mapping research in student engagement and educational technology in higher education: A systematic evidence map. Int. J. Educ. Technol. High. Educ. 2020, 17, 2. [CrossRef]

57. Carini, R.M.; Kuh, G.D.; Klein, S.P. Student engagement and student learning: Testing the linkages. Res. High. Educ. 2006, 47, 1-32. [CrossRef]

58. Kuh, G.D.; Cruce, T.M.; Shoup, R.; Kinzie, J.; Gonyea, R.M. Unmasking the effects of student engagement on first-year college grades and persistence. J. High. Educ. 2008, 79, 540-563. [CrossRef]

59. Czerkawski, B.C.; Lyman, E.W. An instructional design framework for fostering student engagement in online learning environments. TechTrends 2016, 60, 532-539. [CrossRef]

60. Kim, H.J.; Hong, A.J.; Song, H.D. The roles of academic engagement and digital readiness in students' achievements in university e-learning environments. Int. J. Educ. Technol. High. Educ. 2019, 16, 21. [CrossRef]

61. Barefoot, B.O. Higher education's revolving door: Confronting the problem of student drop out in US colleges and universities. J. Open Distance e-Learn. 2004, 19, 9-18. [CrossRef]

62. Hart, C. Factors associated with student persistence in an online program of study: A review of the literature. J. Interact. Online Learn. 2012, 11, 19-42.

63. Hernandez, P.R.; Schultz, P.; Estrada, M.; Woodcock, A.; Chance, R.C. Sustaining optimal motivation: A longitudinal analysis of interventions to broaden participation of underrepresented students in STEM. J. Educ. Psychol. 2013, 105, 89. [CrossRef]

64. Price, D.V.; Tovar, E. Student engagement and institutional graduation rates: Identifying high-impact educational practices for community colleges. Community Coll. J. Res. Pract. 2014, 38, 766-782. [CrossRef]

65. Walters, K.; Henry, P. Fostering Multiple Levels of Engagement in Higher Education Environments; IGI Global: Hershey, PA, USA, 2019

66. Trowler, V. Student engagement literature review. High. Educ. Acad. 2010, 11, 1-15.

67. Bonet, G.; Walters, B.R. High impact practices: Student engagement and retention. Coll. Stud. J. 2016, 50, $224-235$.

68. Laux, D.; Luse, A.; Mennecke, B.E. Collaboration, connectedness, and community: An examination of the factors influencing student persistence in virtual communities. Comput. Hum. Behav. 2016, 57, 452-464. [CrossRef]

69. Swecker, H.K.; Fifolt, M.; Searby, L. Academic advising and first-generation college students: A quantitative study on student retention. NACADA J. 2013, 33, 46-53. [CrossRef] 
70. Dalal, M.; Archambault, L.; Hale, A. Exploring student engagement with digital storytelling content using factor analysis. In Proceedings of the Society for Information Technology \& Teacher Education International Conference, Las Vegas, NV, USA, 18-20 March 2019; Graziano, I.K., Ed.; Association for the Advancement of Computing in Education (AACE): Waynesville, NC, USA, 2019

71. McCormick, A.C.; Kinzie, J.; Gonyea, R.M. Student engagement: Bridging research and practice to improve the quality of undergraduate education. In Higher Education: Handbook of Theory and Research; Springer: Dordrecht, The Netherlands, 2013; Volume 28, pp. 47-92.

72. Barkley, E.F.; Major, C.H. Student Engagement Techniques: A Handbook for College Faculty; John Wiley \& Sons: Hoboken, NJ, USA, 2020

73. Higher Education Surveys. 2015. Available online: https://www.insidehighered.com/news/survey/going-through-motions-20 15-survey-faculty-workplace-engagement (accessed on 12 September 2020).

74. Many Professors Want to Change Their Teaching but Don't. One University Found Out Why. 2019. Available online: https: / / www.chronicle.com/newsletter/teaching/2019-03-21 (accessed on 12 September 2020).

75. Reports on Surveys of Computer Science Faculty and Academic Units/Chairs: COVID-19 Impact. 2020. Available online: https: / / cra.org/reports-on-surveys-of-computer-science-faculty-and-academic-units-chairs-covid-19-impact/ (accessed on 10 September 2020).

76. Bloomberg, L.D. Transitioning Rapidly to Online Teaching: Ten Tips to Prepare Instructors for Success. Int. J. Online Grad. Educ. 2020, 3, 15-24

77. Can a Better Higher Education System Emerge Out of the Coronavirus Crisis. 2020. Available online: https:/ /headfoundation.org/ 2020/06/23/india-can-a-better-higher-education-system-emerge-out-of-the-coronavirus-crisis / (accessed on 10 September 2020).

78. Shaikh, A.; AlReshan, M.S.; Asiri, Y.; Sulaiman, A.; Alshahrani, H. Tele-COVID: A Telemedicine SOA-Based Architectural Design for COVID-19 Patients. CMC-Comput. Mater. Contin. 2020, 67, 549-576. [CrossRef]

79. Hodges, C.; Moore, S.; Lockee, B.; Trust, T.; Bond, A. The difference between emergency remote teaching and online learning Educ. Rev. 2020, 27, 1-9.

80. Shahzad, B.; Javed, I.; Shaikh, A.; Sulaiman, A.; Abro, A.; Memon, M. Reliable Requirements Engineering Practices for COVID-19 Using Blockchain. Sustainability 2021, 13, 6748. [CrossRef]

81. Bozkurt, A.; Sharma, R.C. Emergency remote teaching in a time of global crisis due to CoronaVirus pandemic. Asian J. Dis. Educ. 2020, 15, 1-6.

82. Jung, I. Introduction to theories of open and distance education. In Open and Distance Education Theory Revisited; Springer: Singapore, 2019; pp. 1-9.

83. Kerres, M. Against all odds: Education in Germany coping with COVID-19. Postdigital Sci. Educ. 2020, 2, 690-694. [CrossRef]

84. Gurney, P. Five factors for effective teaching. N. Z. J. Teach. Work 2007, 4, 89-98.

85. Shernoff, D.J.; Csikszentmihalyi, M. Cultivating engaged learners and optimal learning environments. In Handbook of Positive Psychology in the Schools; Routledge; Taylor \& Francis: Oxfordshire, UK, 2009; pp. 131-145.

86. Egan, K. Imagination in Teaching and Learning: The Middle School Years; University of Chicago Press: Chicago, IL, USA, 1992.

87. Shernoff, D.J.; Csikszentmihalyi, M.; Schneider, B.; Shernoff, E.S. Student engagement in high school classrooms from the perspective of flow theory. Sch. Psychol. Q. 2003, 18, 158-176. [CrossRef]

88. Okan, Z. Edutainment: Is learning at risk? Br. J. Educ. Technol. 2003, 34, 255-264. [CrossRef]

89. Christenson, S.L.; Reschly, A.L.; Wylie, C. Handbook of Research on Student Engagement; Springer Science \& Business Media: Berlin/Heidelberg, Germany, 2012.

90. Feldon, D.F. Cognitive load and classroom teaching: The double-edged sword of automaticity. Educ. Psychol. 2007, 42, 123-137. [CrossRef]

91. Hansen, I.G.; Shlesinger, M. The silver lining: Technology and self-study in the interpreting classroom. Interpreting 2007, 9, 95-118. [CrossRef]

92. Sana, F.; Weston, T.; Cepeda, N.J. Laptop multitasking hinders classroom learning for both users and nearby peers. Comput. Educ. 2013, 62, 24-31. [CrossRef]

93. Mick, D.G.; Fournier, S. Paradoxes of technology: Consumer cognizance, emotions, and coping strategies. J. Consum. Res. 1998, 25, 123-143. [CrossRef]

94. Hew, K.F. Use of audio podcast in K-12 and higher education: A review of research topics and methodologies. Educ. Technol. Res. Dev. 2009, 57, 333-357. [CrossRef]

95. Sprenger, J. Stress and Coping Behaviors among Primary School Teachers; East Carolina University: Greenville, NC, USA, 2011.

96. Maguire, R.; Egan, A.; Hyland, P.; Maguire, P. Engaging students emotionally: The role of emotional intelligence in predicting cognitive and affective engagement in higher education. High. Educ. Res. Dev. 2017, 36, 343-357. [CrossRef]

97. Kahu, E. Framing student engagement in higher education. Stud. High. Educ. 2013, 38, 758-773. [CrossRef]

98. Irvine, J.J. Educating Teachers for Diversity: Seeing with a Cultural Eye; Teachers College Press: New York, NY, USA, 2003.

99. Ryan, T.; French, S.; Kennedy, G. Beyond the Iron Triangle: Improving the quality of teaching and learning at scale. Stud. High Educ. 2021, 46, 1383-1394. [CrossRef]

100. French, S. The Benefits and Challenges of Modular Higher Education Curricula; Melbourne Centre for the Study of Higher Education: Melbourne, Australia, 2015. 
101. Engel, S.; Halvorson, D. Neoliberalism, massification and teaching transformative politics and international relations. Aust. J. Political Sci. 2016, 5, 546-554. [CrossRef]

102. Quaye, S.; Harper, S. Student Engagement in Higher Education: Theoretical Perspectives and Practical Approaches for Diverse Populations; Routledge: New York, NY, USA, 2015.

103. Eissa, H.M.S. Pedagogic effectiveness of digital storytelling in improving speaking skills of Saudi EFL learners. Arab World Engl. J. 2019, 10, 127-138. [CrossRef]

104. Khurshid, Z.S. The charismatic blend of learning and teaching styles in the cross-cultural scenario of Jazan University. Procedia Soc. Behav. Sci. 2015, 192, 275-283. [CrossRef]

105. Sulaimani, A. Teaching and Learning in Saudi Arabia: Perspectives from Higher Education; Sense Publisher: New York, NY, USA, 2016.

106. Alamer, S.M. Challenges facing gifted students in Saudi Arabia. Res. Hum. Soc. Sci. 2014, 4, 107-112.

107. Al Qarni, M.A. Evaluation of Provisions for Gifted Students in Saudi Arabia; University of Wollongong: Wollongong, Australia, 2010.

108. Smith, L.; Abouammoh, A. Higher Education in Saudi Arabia; Springer: Dordrecht, The Netherlands, 2013.

109. Alamer, S. Views of Giftedness: The Perceptions of Teachers and Parents Regarding the Traits of Gifted Children in Saudi Arabia; Monash University: Melbourne, Australia, 2010.

110. Hamouda, A. An exploration of causes of Saudi students' reluctance to participate in the English language classroom. Int. J. Engl. Lang. Educ. 2013, 1, 17-34. [CrossRef]

111. Alkhalaf, S.; Nguyen, J.; Nguyen, A.; Drew, S. The potential role of collaborative learning in enhancing e-learning systems: Evidence from Saudi Arabia. In Proceedings of the Australian Society for Computers in Learning in Tertiary Education, Hobart, Australia, 4-7 December 2011.

112. Abdel-Jaber, H. Experimental analysis of students' satisfaction factors in e-Learning environment: A case study on Saudi Arabian University. J. Inf. Knowl. Manag. 2017, 16, 1750018. [CrossRef]

113. Alsamani, A.A.S.; Daif-Allah, A.S. Introducing Project-Based Instruction in the Saudi ESP Classroom: A Study in Qassim University. Engl. Lang. Teach. 2016, 9, 51-64. [CrossRef]

114. Kearsley, G.; Shneiderman, B. Engagement theory: A framework for technology-based teaching and learning. Educ. Technol. 1998, $38,20-23$. 